\title{
Disposition and Practice of Bi-culture Input in Teaching Integrated Course of New College English
}

\author{
Ling $\mathrm{He}^{1}$ Xiaobo Zhang ${ }^{2, *}$ \\ ${ }^{1}$ School of Humanities \& Education Science, Foshan University \\ ${ }^{2}$ Faculty of Foreign Languages, Guangdong Ocean University, Zhanjiang, China \\ *Corresponding author. Email: zhxb601@163.com
}

\begin{abstract}
The western culture has been attached much importance in textbook-compiling whereas Chinese culture as well as the comparison between Chinese and western culture has been neglected to some extent in college English teaching for a long time. As one of the most popular textbooks, the Integrated Course of New College English ( ${ }^{\text {nd }}$ Edition) contains rich cultural topics, but it still focuses too much on the western culture. Based on the notion of "Bi-culture Input", college English teaching can be fulfilled by the following two steps: first, combing the cultural themes according to Byram's evaluation model of cultural contents in textbooks; second, teaching different kinds of themes with different focuses under James' analytical framework of culture in ESL instruction, that is to say, balance in the focus on the learners' culture with a focus on the second language culture, developing culture awareness and empowering learners. The study attempts to construct a college English class model integrating the development of language skills and culture literacy, which aims to cultivate the students' culture awareness, culture self-confidence and their ability to convey Chinese culture in English.
\end{abstract}

Keywords: Integrated Course of New College English (2 ${ }^{\text {nd }}$ Edition), "Bi-culture Input", cultural themes, analytical framework of culture in ESL instruction

\section{INTRODUCTION}

In the past several decades, college English teaching has put more emphases on cultivating students' language skills instead of their cultural literacy. Consequently, in the compilation of college English textbooks, the content of Chinese and foreign cultures was downplayed and the profound influence of Chinese and foreign cultures was ignored, which failed to keep the combination of language and culture in foreign language teaching. To improve this situation, fostering college students' cultural literacy has been accordingly added into College English Teaching Objectives and curricular standards in recent years. For example, The College English Teaching Guide (2017) puts forward the goals of "enhancing students' intercultural communication awareness and communicative competence" and "improving students' comprehensive cultural literacy"; The College English Teaching Curriculum Requirements take "the ability to translate articles reflecting China's national conditions or culture" as a higher requirement for college students' English ability. This paper, with Integrated Course of
New College English (second edition) (hereinafter referred to as "Integrated Course") as the research object, under the guidance of "Bi-culture input" concept, first of all, combs the cultural themes in Integrated Course based on the classification of cultural themes in textbooks posed by Byram, and then explores the approaches of teaching cultural knowledge. We aim to nurture students' cultural awareness, enhance their output capability and evoke their confidence in Chinese culture, by combining the cultivation of language capacity and that of cultural literacy in in-class teaching.

\section{LITERATURE REVIEW OF INTEGRATED COURSE}

Integrated Course is recommended by the Ministry of Education as one of the college English textbooks, and it is also one of the most widely-used college English textbooks in China. Since it came into use, many scholars have carried out a lot of research on it. As early as the end of the last century, the necessity and importance of culture introduction to college English teaching have attracted much attention in China ${ }^{[1][2]}$, and the cultural 
contents in college English textbooks are also of great concern. The research on the cultural knowledge in Integrated Course mainly focuses on the following two aspects: (1) the analysis of its cultural content, such as: Zheng Xiaohong ${ }^{[3]}$ (2009) studies the cultural value orientation and the characteristics of the texts, and $\mathrm{Yu}$ $\operatorname{Ran}^{[4]}$ (2016) categorizes and analyzes the cultural themes in textbooks according to the six classifications of general education ; (2) the approaches of teaching cultural knowledge, such as: Zhang $\mathrm{Ye}^{[5]}$ (2013) discusses the application of Integrated Course to the cross-culture communication teaching, and $\mathrm{Wu}$ Xianyun $^{[6]}$ (2012) explores the strategies of culture input in teaching vocabulary, reading, listening and speaking in New College English. These studies are of great guidance for taking full advantage of textbooks to cultivate students' cultural literacy.

With the deepening of the research on culture input, the integration of Chinese culture into foreign language teaching has been widely recognized and highly valued (Zhang Weimin and Zhu Hongmei, 2002; Yuan Fang, 2006; Zhou Xueting, Xue Shuli, 2019; Etc.) [7][8][9]. However, there is still some lack in the studies on the cultivation of Chinese cultural literacy in teaching Integrated Course. This paper attempts to provide a new route and method for the introduction of Chinese culture in college English classes and the cultivation of students' cultural literacy (both the Chinese culture and the western culture).

\section{THEORETICAL GROUND OF THE SHIFT FROM "MONO-CULTURE INPUT" TO "BI-CULTURE INPUT" IN COLLEGE ENGLISH TEACHING}

Under the background of globalization, in order to achieve China's strategic goal of building a cultural power, college English teaching should be shifted from the sole input of English language skills and culture to "bi-culture input" that adds contents of Chinese culture. This measure will be helpful to solve "Chinese culture aphasia" in foreign language teaching, foster students' intercultural communication competence, and cultivate students' cultural awareness and cultural self-confidence. In this way can we build up cultural self-confidence among diverse cultures in the world, spread the splendid traditional Chinese culture in the world and tell Chinese stories well.

\subsection{To Solve the Problem of "Chinese Cultural Aphasia" in College English Teaching in China}

"Chinese cultural aphasia" is a concept put forward by Cong Cong in the article published in Guangming Daily in 2000. It refers to the phenomenon that Chinese college students are unfamiliar with English expressions of Chinese culture, unable to effectively output Chinese culture in cross-cultural communication, and fail to carry forward the Chinese excellent traditional culture. Cong(2020) also points out the fundamental reason of this phenomenon. "At all levels of English teaching in China, the reform of increasing cultural content in teaching tends to introduce the custom and convention, material culture, system culture and spiritual culture of the English world. However, the Chinese culture, as the cultural background of Chinese students, is almost neglected in English classes" ${ }^{[10]}$.A large number of studies (e.g., Xiao Longfu, Xiao Di, Li Lan, Song Yiwen, 2010; Zhu Min, Xie Hua, Gao Xiaoxi, 2016) ${ }^{[1][12]}$ show that "Chinese cultural aphasia" is a very common problem in college English teaching. According to the questionnaire $^{[13]}$, it is found that college students and college English teachers in China have great expectations for appropriately and adequately adding Chinese cultural knowledge into English classes, and they hope to overcome the problem of 'Chinese cultural aphasia' in English teaching through their joint efforts.

Therefore, increasing the input and reserve of Chinese cultural knowledge in English classes and forming the mode of "bi-culture input" can help students pick up the ability to express Chinese culture fluently and correctly in English and solve the problem of "Chinese cultural aphasia" among college students.

\subsection{To Enhance Students'Intercultural Communication Competence}

"Intercultural communicative competence is the ability to properly use language and cultural knowledge to make effective and appropriate communication with members of different cultures, and it is the decisive factor in intercultural communication activities"[14]. It requires communicators to acquire bi-cultural competence of the mother tongue and the target language, instead of the mono-cultural competence. To some extent, "intercultural communicative competence is the ultimate goal of foreign language education"[15]. However, the English teaching in China fails to achieve this goal. English Teachers in junior and senior middle school give priority to students' acquisition of English language knowledge and skills. College English teachers occasionally touch on western culture, but cultural knowledge isn't one of the teaching focuses, but just the complement and extension of teaching contents, not to mention the input of Chinese cultural classics and splendid culture. Consequently, our classes cannot foster students' cognition of our Chinese culture, which is one aspect of the intercultural communication competence, and in many cases the students cannot conduct successful intercultural communication. Therefore, it's necessary to execute "bi-culture input" in college English teaching to cultivate students' bi-cultural literacy so that they can conduct interactive and effective intercultural communication. 


\subsection{To Cultivate Students' Cultural Awareness and Cultural Self-confidence}

In foreign language education, cultural awareness not only refers to the acquisition of the native culture, but also includes "the critical acceptance of foreign culture and the cultural innovation on the basis of understanding the essence of Chinese and foreign culture"[16]. Cultural awareness and cultural self-confidence are closely related to each other. When students gain cultural awareness, they will naturally build up their cultural self-confidence.

Regarding the approaches of cultivating students' cultural awareness in foreign language education, Lu Wei argues that college English teachers should not "empty the culture of mother tongue" out of classes and exclusively teach the western language and culture. For college students who are developing their ideology in the four-year university period, if they are immersed in the long-term imitation and reception of western culture, they will identify with western culture more than our national culture" and become " a language tool" to some extent ${ }^{[17]}$. Therefore, it is the duty-bound mission of foreign language education to increase the input of Chinese cultural knowledge, cultivate students' cultural awareness and build up their cultural self-confidence on the basis of cultural awareness. In this way, students can participate in intercultural communication actively, confidently and effectively, and they can carry forward and disseminate the Chinese culture in the world. In the context of globalization, cultivating youngsters' cultural awareness and cultural self-confidence can strengthen the economic and cultural cooperation and exchange between China and other countries, promote the dissemination of splendid Chinese culture as well as enhance the national image in the world.

\section{DISPOSITION OF CULTURAL THEMES IN INTEGRATED COURSE}

The 4 books of Integrated Course consist of 32 units totally, and the texts are all selected or adapted from originals of English-speaking authors. In this section, we firstly comb and analyze the allocation of cultural themes in 32 units according to the evaluation model of cultural contents in textbooks which is proposed by Michael $\operatorname{Byram}(1994)^{[18]}$, and then discuss the optimal allocation of the teaching contents related to Chinese culture under the analytical framework of culture in ESL instruction proposed by Mark James(2000) $)^{[19]}$, so as to enhance students' cultural awareness to cover both cultural knowledge and cultural understanding, and improve students' intercultural communication competence.

\subsection{Disposition of Cultural Themes}

Michael Byram(1994:51-52) divides the cultural themes of texts into eight categories from the perspective of intercultural communication, covering all aspects of cultural contents. This all-round classification can be employed to sort out the 32 cultural themes in the four Books of Integrated Course. The 8 categories of cultural themes, the cultural contents involved and the corresponding topics and units in Integrated Course(Book1-4) are shown in Table 1:

Table 1: Category of Cultural Themes in Integrated Course

\begin{tabular}{|c|c|c|}
\hline Category of Cultural Themes & Cultural Contents Involved & Topics and Units in Integrated Course(Book1-4) \\
\hline Social identity and social group & $\begin{array}{c}\text { social class, regional identity , } \\
\text { ethnic minorities }\end{array}$ & $\begin{array}{l}\text { 1. Woman, Half the Sky ( B2U6 ); } \\
\text { 2.Civil-Rights Heroes (B3U2); } \\
\text { 3.Imagination and Creativity (B3U4); } \\
\text { 4. Making a Living (B3U7); } \\
\text { 5. Globalization (B4U4); }\end{array}$ \\
\hline Social interaction & $\begin{array}{c}\text { differing levels of formality ; as } \\
\text { outsider and insider }\end{array}$ & $\begin{array}{ll}\text { 1. } & \text { Friendship(B1U2); } \\
\text { 2. } & \text { Romance(B1U6); } \\
\text { 3. } & \text { Giving Thanks(B3U5); } \\
\text { 4. Never Judge by Appearance(B4U5); } \\
\text { 5. The Pace of Life(B4U6) }\end{array}$ \\
\hline Belief and behavior & $\begin{array}{c}\text { moral , religious beliefs ; daily } \\
\text { routines }\end{array}$ & $\begin{array}{l}\text { 1. The American Dream(B1U4); } \\
\text { 2. Understanding Science; (B1U3) } \\
\text { 3. Work to Live or Live to Work (B1U5); } \\
\text { 4. Values(B2U2); } \\
\text { 5. Cloning(B3U8); }\end{array}$ \\
\hline Social and political institutions & $\begin{array}{c}\text { state institutions, health care } \\
\text { law and order, social } \\
\text { security , local government }\end{array}$ & 1. $\quad$ Security(B3U3) ; \\
\hline Socialization and the life cycle & $\begin{array}{c}\text { families, schools, } \\
\text { employment , rites of passage }\end{array}$ & $\begin{array}{l}\text { 1. } \quad \text { Growing Up(B1U1); } \\
\text { 2. } \quad \text { Animal Intelligence(B1U7); } \\
\text { 3. Educational Problems(B1U8); } \\
\text { 4. Ways of Learning(B2U1); } \\
\text { 5. The Generation Gap(B2U3); } \\
\text { 6. The Virtual World(B2U4); } \\
\text { 7. Overcoming Obstacles(B2U5); } \\
\text { 8. Changes in the Way We Live (B3U1) ; } \\
\text { 9. }\end{array}$ \\
\hline
\end{tabular}




\begin{tabular}{|c|l|l|}
\hline & & $\begin{array}{l}\text { 10. Smart Cars(B4U2); } \\
\text { 11. Job Interview(B4U3); } \\
\text { 12. Go Traveling(B4U8); }\end{array}$ \\
\hline National history & $\begin{array}{c}\text { historical and contemporary } \\
\text { events seen as markers of } \\
\text { national identity }\end{array}$ & $\begin{array}{l}\text { 1.Learning about English(B2U7); } \\
\text { 2. The 9/11 Terrorist Attacks(B4U7); }\end{array}$ \\
\hline $\begin{array}{c}\text { National geography } \\
\text { geographical factors seen as } \\
\text { being significant by member }\end{array}$ & $\begin{array}{l}\text { 1. Protecting Our Environment (B2U8); } \\
\text { 2. Fighting with the Forces of Nature (B4U1); }\end{array}$ \\
\hline $\begin{array}{c}\text { Stereotypes and national } \\
\text { identity }\end{array}$ & national stereotypes
\end{tabular}

On the basis of this classification, we make statistics on the proportion of each category in the total 32 units, and the histogram of their distribution can be shown in the following Figure 1.

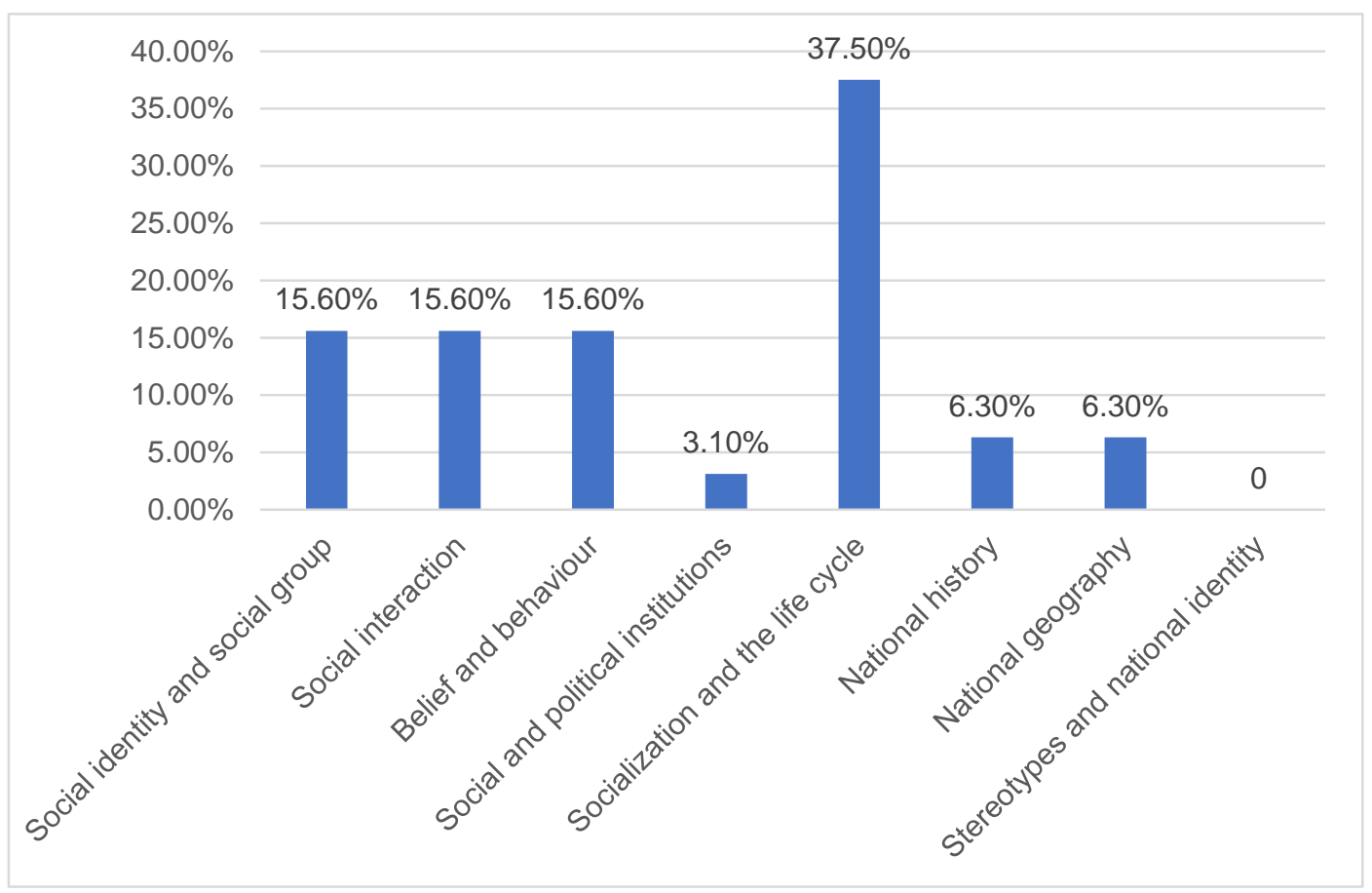

Figure 1:Proportion and Distribution of Cultural Themes in Integrated Course

As can be seen from the above figures, the units in the category of Socialization and the life cycle take up the largest proportion. Most of the unit themes are belonging to the categories such as social life, social communication and social identity, with little involvement in history, geography and politics. In terms of cultural contents, the focus is fixed on daily life rather than on ideology. These themes are not only familiar to college students, but also universal topics in both western culture and Chinese culture. To sum up, the allotment of the cultural themes in Integrated Course is conducive to bi-culture input in teaching, so as to cultivate students' intercultural communication competence and develop their cultural self-confidence.

\subsection{Teaching Practice of Bi-culture Input}

In 2000, Mark James proposed an analytical framework to deal with the input of culture in ESL teaching, which consists of three components: "Balance in the focus on the learners' culture with a focus on the
L2 Culture", "Developing Culture Awareness", and "Empowering Learners". In the teaching practice of Integrated Course in China, these three elements can be further developed into: Balance in the focus on Chinese culture with a focus on the western culture, developing culture awareness at the deep level, and empowering learners to get bilingual competence. This framework is of great guiding significance for foreign language teachers, and is helpful for them to grasp the allocation and method of bi-culture input in the process of foreign language teaching, so as to help learners comprehend the connotation of foreign language culture in the native language environment and make effective output of native language culture in the foreign language context.

\subsubsection{Balance in the focus on Chinese culture with a focus on the western culture}

To some extent, only by understanding a foreign culture can we have a deeper understanding of our own culture; only when one understands one's own national 
culture can one master a foreign culture. That is to say, these two elements are in the relationship of mutual benefit in foreign language learning. After years of learning many subjects and immersion in native culture, college students study the second language(hereinafter referred to as "L2") culture with rich individual learning background and native culture background. If teachers evoke the student's background knowledge in relation to L2 culture, not only can they improve students' cultural awareness of both L2 and their native language, but also they can enhance the efficiency of students' learning L2, enabling students to express more in $\mathrm{L} 2$ about their native culture and L2 that they are learning. Therefore, teachers should balance the focus of their native culture and L2 culture in foreign language teaching.

Among the 32 units in the Integrated Course, an array of themes are very suitable for guiding students to form the interaction between native culture and L2 culture. Take Unit 1 in Book 2 as an example. Its topic is "Ways of Learning" with Text A entitled "Learning, Chinese Style". The author makes a comparison to illustrate the differences in education between China and America. The American education emphasizes "self-reliance" while the Chinese traditional education stresses "teaching by holding his hand". The distinction is caused by their different preferences that American education emphasizes creativity and Chinese education emphasizes basic skills. The author concludes that educators should try to strike a balance between these two extremes. While learning, students are absorbing both Chinese culture and western culture as well. Besides, this topic is closely related to students' life and study, and they are likely to have done some readings on it, or they even have thought about it before. Students may have acquired some background knowledge about it. Therefore, if teachers can stimulate students' background knowledge and form the interaction of two cultures in teaching, students can talk effectively and fluently about Chinese education and American education in English, and their intercultural communication ability will surely be improved. Likewise, other cultural topics in Integrated Course, such as social life, social communication and social identity, can also be dealt with by keeping a good balance in the input of native culture and L2 culture through delicate teaching design.

\subsubsection{Developing Culture Awareness at the Deep Level}

Mark James believes that developing culture awareness "has to do with the kind of cultural information that is included in an ESL program and the way it is presented"[19]. On the basis that the teaching content has been comparatively stipulated in each topical unit, teachers should pay their attention to the way of conveying, which includes teaching cultural information at the surface level and developing cultural understanding at the deep level. Especially to the cultural themes in the category of "Belief and behavior", teachers may give deep and extended guidance to students. To illustrate it, we first take Text A "Tony Trivisonno's American Dream" in B1U4 as an example. It tells the story of an ordinary Italian named Tony Trivisonno who starts his life from scratch in the United States. After his unremitting efforts, he establishes his own company and lives a happy life, realizing his "American dream". Another case is Text A "True Height"(in B4U5), which tells the story of an American athlete who struggles and grows up in the face of adversity. In class, besides explaining the story of these individuals, teachers should reveal the hidden cultural values, and relate them to the phenomenon in Chinese culture, for example: "Chinese dream" put forward by our government, countless stories of sports heroes in China, and so on, in order to let the students deeply understand the profound cultural connotation and develop some thoughts about the differences between Chinese culture and western culture. Therefore, in order to develop students' cultural awareness, we should cultivate students' ability to understand cultural information from the deep level.

\subsubsection{Empowering Learners to Acquire Bilingual Competence}

Foreign language learning should be integrated with learners' personal experience so that they are able to solve real problems in work and life. Mark James states that "a participatory approach in L2 education can enable learners to examine critically the social order and become active in shaping their own role in it" ${ }^{\text {" }}[19] 40$. In the process of participatory learning, they are exposed to the real situations in western culture, and they learn how to solve the problems in that context. At the same time, they will take the initiative to compare it with their native culture, which will undoubtedly deepen the learners' perceptual and rational understanding of the two cultures. After training, they can not only express western culture but also Chinese culture in English. Therefore, foreign language classes should provide learners with opportunities for participatory learning as much as possible, such as making PPT slides to do oral report, role play and group discussions which are very practical and effective means to test learners' perception of bilingual culture and their linguistic competence. In Integrated Course, many unit topics fall into the categories of "social interaction" and "socialization and life cycle", which are suitable to motivate students' participation. For example, for the "Job Interview" topic in Unit 3 of Book 4, students can simulate the job Interview process in English; For Unit 5 of Book 4, which is entitled "Never Judge by Appearances", students may be organized to engage in an English debate on this topic; for the topic of "Romance" in Unit 6 of Book 1, students may be required to make PPT slides and give an oral presentation about Chinese and Western Valentine's Day. Through the participatory 
learning, students learn the English language and culture actively, and meanwhile, they can express Chinese culture in English when they come across something related to their native culture.

\section{CONCLUSION}

Under the background of globalization in the new era and the initiative of "Chinese culture going out", it has become an inevitable requirement for college English teaching to promote bi-cultural education to cultivate students' cultural literacy of both Chinese and English. College students should not only learn western culture, but also carry forward excellent Chinese traditional culture. When teaching Integrated Course, teachers should make full use of the rich cultural contents in textbooks and adopt scientific and diversified teaching methods to carry out bi-culture input. This paper carries a preliminary study on it. The research on Integrated Course should be enriched and deepened to make the teaching practice more scientific in the future.

\section{ACKNOWLEDGMENTS}

This research is funded by the Philosophy and Social Science Research Projects of Guangdong Province (Title: A Study on College English Teaching Model Based on Mobile Assisted Language Learning; No.:GD19WXZ24).

\section{REFERENCES}

[1] Hu,W.Z.(1994)Culture and Communication. Foreign Language Teaching and Research Press, Changsha.

[2] Shu,D.F.(1996)The Relationship between Language and Culture and the Cultural Input in Foreign Language Teaching at the Elementary Stage. Foreign Language World,(01):11-17.

[3] Zheng,X.H.(2009)Presentation of Cultural Value Orientations in Teaching Materials--Taking College English (Integrated Course) as an Example. Foreign Language World,(02):86-91.

[4] Yu,R.(2016)Analysis of College English Integrated Course (second edition):from the Perspective of General Education. Education Modernization, 3(31):141-144+149.

[5] Zhang,Y.(2013)Application of English Textbooks in Cultivating Cross-culture Communication Competence —A Case Study of the New College English(Second Edition).Journal of Jiangxi Normal University( Social Sciences),46(01):132-135.

[6] Wu,X.Y.(2012)On the Importance and Practice of Input of Culture in College English Teaching. Journal of Southwest Minzu University(Humanities and Social Sciences), 33(S1):231-233.

[7] Zhang, W.M.\&Zhu, H.M. (2002) Incorporating
Chinese Culture into College English Teaching. Research On Education Tsinghua University, (S1): 34-40.

[8] Yuan,F.(2006)Analysis of the Status and Role of Mother Tongue Culture in Foreign Language Teaching. Foreign Language Education,(05):67-70.

[9] Zhou, X.T.\&Xue, S.L.(2019)On the Cultivation Strategies of Chinese Cultural Literacy in Universities. Social Sciences in Hunan,(01):153158.

[10] Cong,C.(2000)“Chinese Culture Aphasia”: the Defect of English Education in China. Guangming Daily, 2000-10-19(C01).

[11] Xiao,F.L., Xiao,D., Li,L., Song,Y.W..(2010)A Study of the "Chinese Culture Aphasia" in Present English Education in Chinese Higher Education,Foreign Language Learning Theory and Practice,(01):39-47

[12] Zhu,M., Jie,H., Gao,X.Q..(2016)An Empirical Study of Chinese Traditional Cultural Aphasia in College English Education. Journal of Tianjin Foreign Studies University,23(05):28-32+81.

[13] Song, Y.W.\&Xiao, L.F.(2009)The Present Situation of Chinese Cultural Aphasia in College English Teaching in China, Foreign Languages in China, 6(06):88-92.

[14] Zhang, W.D.\&Yang, L.(2012)Constructing a System of Intercultural Communicative Competence -Based on the Perspective of Foreign Language Education and Empirical Study. Foreign Language World, (02):8-16.

[15] Jia, Y.X.(1997) Intercultural Communication. Shanghai Foreign Language Education Press, Shanghai.

[16] Yuan, X.L.\&Zhao,J.(2017)Appeals and Solutions to the Cultivation of Cultural Awareness Foreign Language Education Under the Background of "The Belt and Road Initiative". Journal of Xi'an International Studies University,25(03):69-72.

[17] Guo,J.(2003)How does Literature Get along with Linguistics-- the Meeting Summary of 2002 Foreign Literature Annual Conference. Foreign Language Teaching and Research,(02):145-150.

[18] Byram, M.\&Morgan,C.(1994)Defining and Assessing Intercultural Competence: Some Principles and Principles for the European Context. Council of Europe, Print.

[19] James, M.(2000)Culture in ESL Instruction: An Analytic Framework[J].Tesl Canada Journal, 17(2): 36-49. 